\title{
Transmission of infectious hematopoietic necrosis virus in seawater
}

\author{
G. S. Traxler, J. R. Roome, M. L. Kent \\ Department of Fisheries and Oceans, Pacific Biological Station, Nanaimo, British Columbia, Canada V9R 5K6
}

\begin{abstract}
The susceptibility of Atlantic (Salmo salar), sockeye (Oncorhynchus nerka), and chinook salmon (O. tshawytscha) post-smolts to infection with infectious hematopoietic necrosis virus (IHNV) in seawater was determined. Fish were challenged in seawater by cohabitation with fish intraperitoneally injected with IHNV, and by IHNV bath exposure. Atlantic salmon were susceptible to IHNV infection by both cohabitation and bath exposure. Sockeye salmon were infected by cohabitation with viral injected Atlantic salmon, but not by bath exposure. Chinook salmon were refractory to infection. Infected Atlantic salmon exhibited severe petechial and ecchymotic hemorrhages in the viscera, pale livers, bloody ascites, and anemia. This study indicates that IHNV poses a threat to Atlantic salmon reared in seawater and, therefore. the introduction of infected fish to netpens should be avoided.
\end{abstract}

\section{INTRODUCTION}

Infectious hematopoietic necrosis (IHN) is a serious disease of several species of juvenile Pacific salmon reared in fresh water, particularly sockeye salmon Oncorhynchus nerka. In British Columbia, Canada, IHN virus has caused severe losses among sockeye and kokanee (non-anadromous $O$. nerka) salmon and cultured rainbow trout Oncorhynchus mykiss (Amend et al. 1969, Traxler 1986, Traxler \& Rankin 1989). In Washington and Oregon, USA, resident and anadromous rainbow trout (steelhead) have suffered losses due to IHN virus (Mulcahy et al. 1980) and in California, USA, the virus has killed chinook salmon Oncorhynchus tshawytscha (Wingfield \& Chan 1970). Commercial aquaculture facilities in Idaho, USA, have also experienced losses among rainbow trout (Busch 1983) and recently, the disease has been reported among rainbow trout in Europe (Baudin-Laurencin 1987, Bovo et al. 1987). An epizootic of IHN in Atlantic salmon fry Salmo salar reared in water containing a feral population of sockeye salmon demonstrated their susceptibility to the virus (Mulcahy \& Wood 1986).

The most severe losses due to IHN virus occur during the yolk-sac and early swim-up stages (Pilcher \& Fryer 1980). Generally, as fish become older, resistance to
IHN increases; however, there have been reports of IHN causing losses among 2 yr old kokanee and sockeye smolts, and rainbow trout (Busch 1983, Burke \& Grischkowsky 1984, Traxler 1986). It is well recognized that waterborne transmission occurs in fresh water (Pilcher \& Fryer 1980) but nothing is known about the transmission of IHN virus, or susceptibility of fish to the disease, in seawater. The stability of IHN virus has been studied in both fresh and seawater. The IHN virus has been demonstrated to survive in fresh water at $10^{\circ} \mathrm{C}$ for $7 \mathrm{wk}$ (Wedemeyer et al. 1978). In seawater the virus was found to decrease by $3 \log _{10}$ over a 3 wk period at $15^{\circ} \mathrm{C}$ (Toranzo \& Hetrick 1982) Winton et al. (1991) found that the titer of IHNV in fresh water was reduced $20 \times$ while in salt water the titer decreased $8 \times$ over $1 \mathrm{~h}$.

Rearing of salmonid fishes in seawater netpens is a rapidly growing industry in British Columbia (B.C.), and problems due to IHN in netpens have not yet occurred. Therefore, we investigated the susceptibility and transmission of IHN in chinook and Atlantic salmon, the 2 most important salmon species used in netpen aquaculture in B.C. Sockeye salmon were also included in the study because the infection is prevalent in this species in B.C. and because their culture in seawater netpens is being investigated. 


\section{METHODS}

Virus. The IHN virus used in this study was isolated from post-spawned sockeye salmon from Fulton River, B.C. The isolate was characterized as type 1 electropherotype by analysis of the molecular weights of the viral proteins (J. Leong, Oregon State Univ., pers. comm.). The virus was grown in epithelioma papillosum cyprini (EPC) cells and passed twice in cell culture prior to storage at $-85^{\circ} \mathrm{C}$.

Fish. Atlantic salmon fry with an average wt of $1.55 \mathrm{~g}$ were challenged in ambient fresh water at $12.0^{\circ} \mathrm{C}$. Atlantic (avg wt $86.9 \mathrm{~g}$ ), chinook (avg wt $40.8 \mathrm{~g}$ ), and sockeye salmon smolts (avg wt $19.2 \mathrm{~g}$ ) were acclimated to seawater over a period of $3 \mathrm{~d}$. They were held in $9.0^{\circ} \mathrm{C}$ seawater for $1 \mathrm{wk}$ prior to exposure to virus. All fish were fed daily with a commercial diet. Prior to exposure, all groups were tested and found to be negative for the presence of IHN virus.

Challenge protocol. The pathogenicity of the viral isolate was confirmed by bath exposure of Atlantic salmon fry (avg wt $1.55 \mathrm{~g}$ ) in fresh water. Duplicate groups of 20 fish were exposed to $5.65 \times 10^{3}$ plaqueforming units (pfu) $\mathrm{ml}^{-1}$ for $2 \mathrm{~h}$. Water temperature during the experiment was maintained at $12{ }^{\circ} \mathrm{C}$.

Virus challenges in seawater $(28 \%$ ) were conducted by intraperitoneal injection, bath exposure, and cohabitation. Ten fish of each of the 3 species were injected with $1.6 \times 10^{3}$ pfu of IHN virus. These fish were fin-clipped for identification and placed in separate tanks ( 1 species tank ${ }^{-1}$ ) to serve as a source of virus for the cohabitation challenge. The following numbers of fish were added to the tanks containing the injected fish: 22 Atlantic and 25 sockeye salmon to the tank containing the injected sockeye salmon; 20 Atlantic, 25 chinook, and 25 sockeye salmon to the tank with the injected Atlantic salmon; 20 Atlantic and 20 chinook salmon to the tank containing the injected chinook salmon. The bath exposures were conducted by immersing 20 fish of each species in seawater containing IHN virus for $3 \mathrm{~h}$. The initial viral titer of the challenge suspension was $8.98 \times 10^{3} \mathrm{pfu} \mathrm{ml}^{-1}$, but the titer had decreased to $2.70 \times 10^{3}$ after $3 \mathrm{~h}$. All groups of fish were held in 7301 tanks with seawater at $9^{\circ} \mathrm{C}$ (flow rate of $321 \mathrm{~min}^{-1}$ ). The fish were fed a commercial ration and monitored daily for losses.

Assay procedures. Kidney and spleen tissues from each dead fish were pooled and tested for IHN virus by plaque assay (Burke \& Mulcahy 1980). The presence of bacterial pathogens was determined by examination of Gramstained kidney smears and by plating kidney tissue on tryptic soy agar. At the end of each experiment, surviving fish were examined for IHN virus by assaying gill, kidney/spleen, and mucus samples individually for virus.

Histology. Visceral organs from all moribund fish were preserved in Davidson's solution (Humason 1979) and processed for light microscopy using standard histological techniques.

\section{RESULTS}

\section{Challenge in fresh water}

Bath exposure of Atlantic salmon fry resulted in 9 of 20 exposed fish in each challenge group dying of IHN, indicated by high IHN viral titers in these fish (Table 1). Three fish from Tank 1 died from causes other than IHN. This challenge experiment was terminated after $35 \mathrm{~d}$, and all remaining fish were assayed for IHN virus. The 8 fish surviving in Tank 1 were virus negative. Of the 11 surviving fish from Tank 2,2 fish

Table 1. Mortality, prevalence, and titer of IHN virus in dead Atlantic salmon fry exposed to IHN virus in fresh water. Fish in Tanks $1 \& 2$ were exposed to IHN virus at a level of $5.65 \times 10^{3} \mathrm{pfu} \mathrm{m}^{-1}$ for $2 \mathrm{~h}$. Fish in

Tank 3 were unexposed and served as controls

\begin{tabular}{|lccc|}
\hline $\begin{array}{l}\text { Bath } \\
\text { exposure }\end{array}$ & $\begin{array}{c}\text { Cumulative } \\
\text { mortality }\end{array}$ & $\begin{array}{c}\text { Mean time to } \\
\text { death }(\mathrm{d})\end{array}$ & $\begin{array}{c}\text { Mean viral titer } \\
\text { pfu g }^{-1} \text { (fish) }\end{array}$ \\
\hline Tank 1 & $12 / 20(9 / 12$ IHN+) & 8.7 & $9.9 \times 10^{5}$ \\
Tank 2 & $9 / 20(9 / 9$ IHN+) & 9.2 & $2.3 \times 10^{6}$ \\
Tank 3 & $2 / 20(0 / 20$ IHN+) & - & 0.0 \\
\hline
\end{tabular}

Table 2. Bath challenge and intraperitoneal injection of salmonids held in seawater with IHN virus. Fish were bath-challenged by holding them in seawater containing $8.98 \times 10^{3} \mathrm{pfu} \mathrm{ml}^{-1} \mathrm{IHN}$ virus for $3 \mathrm{~h}$; they were injection-challenged intraperitonally with $1.6 \times 10^{3}$ pfu of IHN virus. Mean viral titer calculated from dead or moribund fish

\begin{tabular}{|lcccc|}
\hline $\begin{array}{l}\text { Challenge } \\
\text { method }\end{array}$ & $\begin{array}{c}\text { Cumulative } \\
\text { mortality }\end{array}$ & $\begin{array}{c}\text { Mean time } \\
\text { to death } \\
\text { (d) }\end{array}$ & $\begin{array}{c}\text { First } \\
\text { mortality } \\
\text { (d) }\end{array}$ & $\begin{array}{c}\text { Mean viral titer } \\
\left(\mathrm{pfu} \mathrm{g}^{-1}\right)\end{array}$ \\
\hline $\begin{array}{c}\text { Bath } \\
\text { Atlantic }\end{array}$ & $2 / 20$ & 24 & 19 & $7.1 \times 10^{4}$ \\
Chinook & $0 / 20$ & - & - & 0.0 \\
Sockeye & $0 / 20$ & - & - & 0.0 \\
Injection & & & & \\
Atlantic & $8 / 10$ & 14 & 11 & $3.3 \times 10^{5}$ \\
Chinook & $0 / 10$ & - & - & 0.0 \\
Sockeye & $4 / 10$ & 8 & 4 & $6.9 \times 10^{6}$ \\
\hline
\end{tabular}


were positive with viral titers of $3.4 \times 10^{2}$ and $7.3 \times 10^{3}$ pfu $\mathrm{g}^{-1}$ of whole fish. Virus was not detected in any of the unexposed fish from Tank 3.

\section{Challenges in seawater}

The bath exposures of Atlantic, sockeye, and chinook salmon resulted in infection of only Atlantic salmon (Table 2). Ten percent of the Atlantic salmon developed IHN and all of these fish apparently died from the disease. The experiment was terminated after $8 \mathrm{wk}$, and all surviving fish were assayed for IHN virus. Only gill tissue from 1 sockeye was positive for IHN virus, with a titer of $2.0 \times 10^{1} \mathrm{pfu}^{-1}$ of tissue.

Injection of IHN virus also resulted in higher losses among the group of Atlantic salmon with the cumulative mortality reaching $80 \%$ (Table 2 ). Sockeye salmon suffered a $40 \%$ loss and chinook salmon did not experience any mortality. Viral assays at $8 \mathrm{wk}$ post-exposure were negative for all surviving fish.

Only Atlantic salmon developed IHN when maintained with infected sockeye (Table 3) while in the tank with infected Atlantic salmon, 1 sockeye and several Atlantic salmon developed IHN. Injected chinook salmon were refractory and did not transmit IHN to either chinook or Atlantic salmon.

At $12 \mathrm{wk}$ post-exposure, virus assays on surviving fish from the cohabitation experiment revealed 1 IHN virus positive sockeye salmon, the species previously felt to be the most susceptible to this strain of IHN. The positive sockeye was from the tank that held the injected Atlantic salmon. The gill, mucus, and kidneyf spleen pools were positive for IHN virus with titers of

Table 3. Transmission of IHN by cohabitation with infected salmon. Ten fish injected with $1.6 \times 10^{5} \mathrm{pfu}$ of IHN virus served as the source of infection in each of the tanks. Mean viral titers are from dead or moribund fish

\begin{tabular}{|lcccc|}
\hline $\begin{array}{l}\text { Cohabitation } \\
\text { with: }\end{array}$ & $\begin{array}{c}\text { Cumulative } \\
\text { mortality }\end{array}$ & $\begin{array}{c}\text { Mean time } \\
\text { to death } \\
\text { (d) }\end{array}$ & $\begin{array}{c}\text { First } \\
\text { mortality } \\
\text { (d) }\end{array}$ & $\begin{array}{c}\text { Mean viral } \\
\text { titer } \\
\left(\mathrm{pfu} \mathrm{g}^{-1}\right)\end{array}$ \\
\hline $\begin{array}{l}\text { Injected sockeye } \\
\text { Atlantic } \\
\text { Sockeye }\end{array}$ & $2 / 22$ & 27 & 21 & $1.2 \times 10^{6}$ \\
Injected Atlantic & $0 / 25$ & - & - & 0.0 \\
$\quad$ Atlantic & $6 / 22$ & 25 & 19 & $1.2 \times 10^{6}$ \\
$\quad$ Chinook & $0 / 25$ & - & - & 0.0 \\
$\quad$ Sockeye & $1 / 25$ & 37 & 37 & $1.6 \times 10^{3}$ \\
Injected chinook & & & & \\
$\quad \begin{array}{l}\text { Atlantic } \\
\text { Chinook }\end{array}$ & $0 / 20$ & - & - & 0.0 \\
& $0 / 20$ & - & - & 0.0 \\
\hline
\end{tabular}

$3.4 \times 10^{4}, 1.8 \times 10^{3}$, and $2.3 \times 10^{4} \mathrm{pfu}^{-1}$, respectively. No virus was detected in surviving chinook and Atlantic salmon.

All affected fish were dark and lethargic, but showed no external lesions. Internally, infected Atlantic salmon exhibited severe petechial and ecchymotic hemorrhages in the viscera, pale livers, bloody ascites, and anemia. In contrast, sockeye salmon exhibited only pallor of the gills, liver, and kidney. Histologically, Atlantic salmon displayed massive necrosis of the hematopoietic cells in the kidney interstitium and extensive diffuse necrosis in the spleen and in the submucosa and lamina propria of the pyloric caeca and lower intestine. The histopathological changes observed in the Atlantic salmon were more severe than those seen in the sockeye salmon, but the latter exhibited similar lesions.

\section{DISCUSSION}

This study demonstrates for the first time that both Atlantic and sockeye salmon are susceptible to infection with IHN virus in seawater by waterborne exposure and by cohabitation with infected fish. The study also demonstrated that older and larger juvenile salmonids are vulnerable to infection with IHN virus. Chinook salmon are also susceptible to IHN (Parisot et al. 1965). The failure to transmit IHN to this species may have been due to the use of type 1 IHN virus in the challenge experiments. Type 3 IHN strain from California has been shown to be pathogenic for chinook salmon (LaPatra 1989). Only type 1 IHN, the strain used in this study, has been isolated from sock-

eye salmon in B.C. and this and other studies suggest that chinook, at least smolt-sized chinook, are refractory to this strain (LaPatra 1989). It was previously believed that sockeye salmon were the most susceptible species to the type 1 strain; however, our study indicates that Atlantic salmon are more susceptible to the virus than sockeye salmon. The results also suggest that Atlantic salmon produce, and presumably release, higher titers of virus than sockeye.

The marked susceptibility of Atlantic salmon noted in this study is of importance to the aquaculture industry in B.C., as well as to netpen farming on a global basis, because of increasing dependence upon the culture of this species. We have recently confirmed the first outbreak of IHN in pen-reared Atlantic salmon in B.C., but the gross signs caused by IHN are similar to those seen in Gram-negative bacterial septicemias, and viral assays 
are not routinely carried out on netpen-reared fish in B.C. The disease may therefore be more prevalent than is presently recognized, and virus assays should be considered when examining pen-reared fish with these clinical signs.

A possible explanation for the greater susceptibility of Atlantic salmon to IHN is that this fish is exotic to the Pacific Northwest and, therefore, probably has less innate resistance to the virus than indigenous salmonid species. This is probably a good example of the increased disease risk posed to a newly introduced animal species by an enzootic pathogen.

Acknowledgements. The authors thank Dr T. P. T. Evelyn for his critical review of the paper.

\section{LITERATURE CITED}

Amend, D. F., Yasutake, W. T., Mead, R. W. (1969). A hematopoietic virus disease of rainbow trout and sockeye salmon. Trans. Am. Fish. Soc, 4: 796-804

Baudin-Laurencin, F. (1987). IHN in France. Bull. Eur. Ass. Fish Pathol. 7: 104

Bovo, G., Giogetti, G., Jorgesen, P. E. V., Olesen, N. J. (1987). Infectious haematopoietic necrosis: first detection in Italy. Bull. Eur. Ass. Fish Pathol. 7: 124

Burke, J., Grischkowsky, R. (1984). An epizootic caused by infectious hematopoietic necrosis virus in an enhanced population of sockeye salmon, Oncorbynchus nerka (Walbaum), smolts at Hidden Creek, Alaska. J. Fish Dis. 7 : 421-429

Burke, J., Mulcahy, D. (1980). Plaquing procedure for infectious hematopoietic necrosis virus. Appl. environ. Microbiol. 39: 872-876

Busch, R. A. (1983). Viral disease considerations in the commercial trout industry in Idaho. In: Leong, J. C., Barila, T. Y. (eds.) Workshop on viral diseases in the Columbia River basin. Bonneville Power Administration, Portland, OR, p. $84-100$

Humason, G. L. (1979). Animal tissue techniques. W. H. Freeman and Co., San Francisco

LaPatra, S. E. (1989). Strain differentiation and detection of

Responsible Subject Editor: F. M. Hetrick, College Park, Maryland, USA infectious hematopoietic necrosis virus. Ph.D. dissertation, Oregon State University, Corvallis

Mulcahy, D. M., Tebbit, G. L., Groberg, W. J., McMichael, J. S., Winton, J. R., Hedrick, R. P., Philippon-Fried, M., Pilcher, K. S., Fryer, J. L. (1980). The occurrence and distribution of salmonid viruses in Oregon. Oregon State Univ. Sea Grant College Program, Corvallis, ORESU-T80-004: $1-71$

Mulcahy, D., Wood, J. (1986). A natural epizootic of infectious hematopoietic necrosis in imported Atlantic salmon, Salmo salar L., reared in the enzootic region. J. Fish Dis. 9: $173-175$

Parisot, T. J., Yasutake, W. T., Klontz, G. W. (1965). Viral diseases of the Salmonidae in the western United States. I. Etiology and epizootiology. Annls N.Y Acad. Sci. 126: $502-519$

Pilcher, K. S., Fryer, J. L. (1980). The viral diseases of fish: a review through 1978. Part 1: Diseases of proven viral etiology. CRC crit. Rev. Microbiol. 7: 287-363

Traxler, G. S. (1986). An epizootic of infectious hematopoietic necrosis in 2-yr-old kokanee, Oncorhynchus nerka (Walbaum) at Lake Cowichan, British Columbia. J. Fish Dis. 9: 545-549

Traxler, G. S., Rankin, J. B. (1989). An infectious hematopoietic necrosis epizootic in sockeye salmon Oncorhynchus nerka in Weaver creek spawning channel, Fraser River system, B.C., Canada. Dis. aquat. Org. 6: $221-226$

Toranzo, A. E., Hetrick, F. M. (1982). Comparative stability of two salmonid viruses and poliovirus in fresh, estuarine and marine waters. J. Fish Dis. 5: 223-231

Wedemeyer, G. A., Nelson, N. C., Smith, C. A. (1978). Survival of salmonid viruses infectious hematopoietic necrosis (IHNV) and infectious pancreatic necrosis (IPNV) in ozonated, chlorinated and untreated waters. J. Fish. Res. Bd Can. 35: 875-879

Wingfield, W. H., Chan, L. D. (1970). Studies on the Sacramento river chinook disease and its causative agent. In: Snieszko, S. F. (ed.) A symposium on diseases of fishes and shellfishes. Am. Fish. Soc. Spec. Publ. 5: 308-318

Winton, J. R., Batts, W. N., Deering, R. E., Brunson, R., Hopper, K., Nishizawa, T., Stehr, C. (1991). Characteristics of the first North American isolates of viral hemorrhagic septicemia virus. Proceedings, Second International Symposium on Viruses of Lower Vertebrates, July 29-31, 1991. Oregon State Univ. Press, Corvallis, p. 13-50

Manuscript first received: November 20, 1992

Revised version accepted: March 8, 1993 